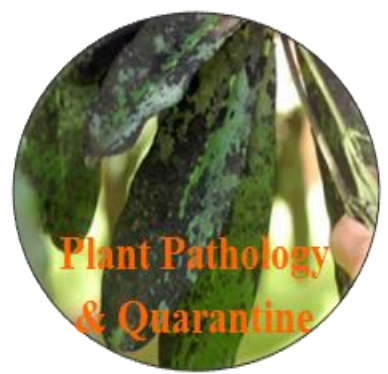

\title{
Erysiphe australiana causing powdery mildew on crape myrtle (Lagerstroemia indica) in Mexico
}

\section{Márquez-Licona G', Solano-Báez AR¹, Pérez-López $\mathbf{M}^{2}$, Leyva-Mir SG3 ${ }^{3}$, Tovar- Pedraza $\mathbf{J M}^{3 *}$}

${ }^{1}$ Colegio de Postgraduados, Campus Montecillo, Fitopatología. Carretera México-Texcoco km. 36.5, Montecillo, 56230, Estado de México, Mexico.

${ }^{2}$ Colegio de Postgraduados, Campus Montecillo, Botánica. Carretera México-Texcoco km. 36.5, Montecillo, 56230, Estado de México, Mexico.

${ }^{3}$ Universidad Autónoma Chapingo, Departamento de Parasitología Agrícola. Carretera México-Texcoco km. 38.5, Chapingo, 56230, Estado de México, Mexico.

Márquez-Licona G, Solano-Báez AR, Pérez-López M, Leyva-Mir SG, Tovar-Pedraza JM. 2018 Erysiphe australiana causing powdery mildew on crape myrtle (Lagerstroemia indica) in Mexico. Plant Pathology \& Quarantine 8(1), 48-51, Doi 10.5943/ppq/8/1/6

\begin{abstract}
During January to April 2017, typical symptoms of powdery mildew were observed on leaves and inflorescences of crape myrtle (Lagerstroemia indica) in parks of Mexico City and State of Mexico, Mexico. The fungus was identified by morphological characters of the asexual stage. Pathogenicity tests were conducted and Koch's postulates were fulfilled. Based on morphological features, the fungus on L. indica was identified as Erysiphe australiana. To our knowledge, this is the first report of Erysiphe australiana causing powdery mildew on L. indica in Mexico.
\end{abstract}

Key words - Erysiphales - fungus - morphology - pathogenicity

\section{Introduction}

Crape myrtle (Lagerstroemia indica) belongs to the family Lythraceae and is a widely commercialised ornamental shrub or small tree that is often planted in gardens, public parks, buffer strips around parking lots, and along highways. It has escaped from cultivation and become naturalized in waste ground, disturbed sites, open grasslands, and along roadsides in many climates (CABI 2017).

Powdery mildew is the most widely recognized and possibly the most commonly reported disease on crape myrtles. It usually does not significantly threaten plant health, but heavily colonized foliage and flower buds are unattractive and may render damaged plants unsalable (Hagan 2001).

Three powdery mildew fungi, Erysiphe australiana, Pseudoidium yenii (Braun \& Cook 2012), and Phyllactinia lagerstroemiae (Meeboon \& Takamatsu 2017), have been reported on Lagerstroemia spp. worldwide. However, the specific identity of the pathogen on Lagerstroemia spp. in Mexico has not been determined.

In 2017, severe symptoms of powdery mildew were observed on crape myrtle plants located in parks of Mexico City and State of Mexico, Mexico. The aim of this study was to identify the 
causal agent of powdery mildew on L. indica in Mexico, based on morphological characterization and pathogenicity tests.

\section{Materials \& Methods}

\section{Sample collection}

During January to April 2017, material of crape myrtle showing symptoms and signs of powdery mildew was collected in parks of Coyoacán, Mexico City and Texcoco, State of Mexico, Mexico. Diseased plants had abundant mycelial growth and whitish sporulation mainly on the lower surface of the leaves and on inflorescences. Affected plant parts often became distorted and fully covered with a white sporulation. A voucher specimen (UACH-H141) was deposited in the Herbarium of the Department of Agricultural Parasitology at the Chapingo Autonomous University (Texcoco, State of Mexico, Mexico).

\section{Morphology}

For the morphological characterization, fungal structures were mounted in a drop of lactic acid on a glass slide. Thirty conidiophores and 100 conidia were examined using an Eclipse Ni-U light microscope (Nikon Corporation, Minato, Tokyo, Japan) and micrographs were taken with a Moticam 580 camera (Motic, Hong Kong, China).

\section{Pathogenicity test}

Pathogenicity of the fungus was demonstrated through inoculation by gently dusting conidia from infected leaves onto healthy leaves of 10 detached twigs of crape myrtle plants. Five noninoculated twigs served as controls. Twigs were kept with their end in water and maintained in a glasshouse at temperatures ranging from 20 to $30^{\circ} \mathrm{C}$. Pathogenicity test was repeated twice.

\section{Results}

The morphological characteristics were consistent with those of the anamorphic stage of Erysiphe australiana (McAlpine) U. Braun \& S. Takam. (Braun \& Cook 2012). Microscopic examination showed effuse, amphigenous mycelium on leaves and on inflorescences. Hyphal appressoria were multilobed, mostly solitary, occasionally in opposite pairs. Conidiophores were erect, hyaline, 55-90 × 7.8-11.4 $\mu \mathrm{m}$. Foot-cells were cylindrical, sometimes slightly flexuous, $22-$ $35 \times 7.8-11.4 \mu \mathrm{m}$, followed by $2-3$ shorter cells. Conidia were formed singly, cylindrical to ellipsoid, hyaline, 26-39 × 12.2-16.6 $\mu \mathrm{m}$. Fibrosin bodies were absent. Germ tubes were subterminal, straight to flexuous. Conidial appressoria were multilobed to moderately lobed. Chasmothecia were not observed.

In the pathogenicity tests, inoculated leaves developed powdery mildew symptoms 10 days after inoculation, whereas the control leaves remained healthy. The fungus present on the inoculated leaves was morphologically identical to that originally observed on diseased plants, fulfilling Koch's postulates.

\section{Discussion}

Based on morphological features, the fungus on Lagerstroemia indica was identified as Erysiphe australiana. This fungal species has been previously reported causing powdery mildew on Lagerstroemia spp. in Argentina (Delhey et al. 2003), Brazil (Liberato \& Barreto 2004, Fonseca et al. 2015), USA (Shi \& Mmbaga 2006), Turkey (Göre 2009), India (Baiswar et al. 2009), China, Taiwan, Japan, Korea, Russia, Italy, Portugal, Spain, Switzerland, United Kingdom, Ukraine, South Africa, Australia, and New Zealand (Braun \& Cook 2012). In Mexico, García-Álvarez (1976) mentioned the presence of Oidium sp. on L. indica, but that report was not supported by morphological characterization nor by pathogenicity tests. To our knowledge, this is the first report of Erysiphe australiana causing powdery mildew on L. indica in Mexico. 

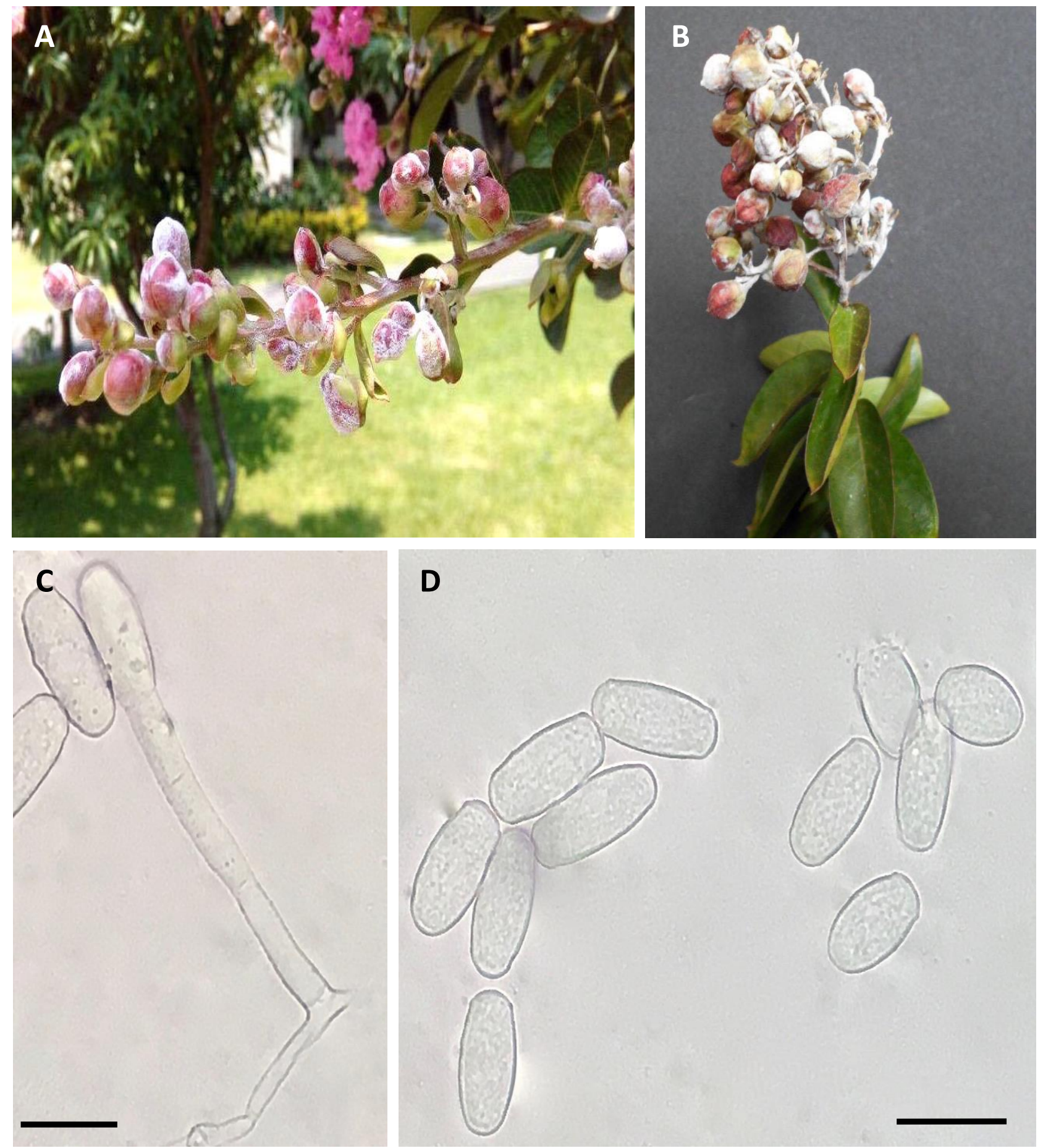

Fig. 1 - Powdery mildew of Lagerstroemia indica caused by Erysiphe australiana. A, B Severe infection on inflorescences, C Conidiophore with conidium, D Conidia - Bars: C $=25 \mu \mathrm{m}, \mathrm{D}=30$ $\mu \mathrm{m}$.

According to Hagan (2001), strategies for controlling powdery mildew on crape myrtle in container and field nurseries are limited to the production of disease resistant cultivars and the use of protective fungicides. In addition, differences in susceptibility of crape myrtle cultivars to powdery mildew have been observed in field trials.

\section{References}


Baiswar P, Chandra S, Ngachan SV. 2009 - First report of anamorphic Erysiphe australiana on Lagerstroemia speciosa in India. Australasian Plant Disease Notes 4, 49.

Braun U, Cook RTA. 2012 - Taxonomic Manual of the Erysiphales (Powdery Mildews). CBS, Utrecht, The Netherlands: CBS Biodiversity Series No. 11, 707 p.

CABI. 2017 - Lagerstroemia indica (Indian crape myrtle). In: Invasive Species Compendium. CABI Publishing, Wallingford, UK. Document description.

Delhey R, Braun U, Kiehr M. 2003 - Some new records of powdery mildew fungi from Argentina (2). Schlechtendalia 10, 79-90.

Fonseca NR, Guimarães LMS, Pires RP, Alfenas AC. 2015 - Erysiphe australiana: the cause of powdery mildew on Lagerstroemia speciosa in Brazil. Forest Pathology 46(4), 366-368.

García-Álvarez M. 1976 - Primer catálogo de enfermedades de plantas mexicanas. Fitofilo 71, 45169.

Göre ME. 2009 - Powdery mildew caused by Erysiphe sp. on Lagerstroemia indica newly reported in Turkey. Plant Pathology 58, 397.

Hagan AK. 2001 - Crapemyrtle diseases. In: Jones RK, Benson DM (Eds). Diseases of Woody Ornamentals and Trees in Nurseries. St. Paul, Minnesota, USA, APS Press, p. 114-116.

Liberato JR, Barreto RW. 2004 - Anamorphic stage of Erysiphe australiana causing powdery mildew on Lagerstroemia indica in Brazil. Plant Pathology 53, 808.

Meeboon J, Takamatsu S. 2017 - First found of Erysiphe elevata on Eucalyptus camaldulensis and Phyllactinia lagerstroemiae sp. nov. on Lagerstroemia from Thailand. Mycoscience 58(4), 253-260.

Shi A, Mmbaga MT. 2006 - Perpetuation of powdery mildew infection and identification of Erysiphe australiana as the crape myrtle pathogen in mid-Tennessee. Plant Disease 90, 1098-1101. 